\title{
Trophic state and recreational value of Lake Mikołajskie
}

\author{
Justyna Sieńska, Julita Dunalska, Michał Łopata, Katarzyna Parszuto, Renata Tandyrak
}

\author{
Department of Water Protection Engineering, University of Warmia and Mazury, Prawocheńskiego 1, 10-957 Olsztyn, Poland, \\ e-mail: justyna.sienska@uwm.edu.pl, julita.dunalska@uwm.edu.pl (corresponding author), michal.lopata@uwm.edu.pl, \\ kasiapar@uwm.edu.pl,renatat@uwm.edu.pl
}

\begin{abstract}
Lakes along with their surroundings are an attractive landscape component that play an important role in recreation and relaxation. In Poland, the Great Masurian Lakeland, visited by a million tourists every year, is considered to be the most attractive lake area. However, tourist pressure has several negative effects which cause degradation of the water environment. The aim of this study was to determine the trophic state of Lake Mikołajskie which is a hub for sailing and motorboating traffic. Values of the trophic status index were calculated from the content of total phosphorus, chlorophyll $a$ and Secchi disc visibility, according to the data from the Voivodeship Inspectorate for Environmental Protection. In summer, the concentration of total phosphorus was $0.019-0.042 \mathrm{mg} \mathrm{dm}^{-3}$ in 2013 and $0.022-0.055 \mathrm{mg} \mathrm{dm}^{-3}$ in 2014. The concentration of chlorophyll $a$ was in the range of $8.3-45.0 \mu \mathrm{g} \mathrm{dm} \mathrm{dm}^{-3}$ in 2013 and $8.9-22.0 \mu \mathrm{g} \mathrm{dm}^{-3}$ in 2014 . The maximum visibility of Secchi disc reached $2.0 \mathrm{~m}$ (2013) and $1.8 \mathrm{~m}$ (2014). Based on the calculated, Lake Mikołajskie can be classified as a eutrophic lake. In order to protect lakes from degradation tourists should be educated about the rational use of surface waters and the surrounding catchment. However, it is not only the massive influx of tourists, but also the activity of residents (dictated by economic reasons) that contribute to the pollution of lakes. Therefore, the development of tourism and the economy of the whole region should be harmonious and balanced so that the natural resources can serve us and future generations for as long as possible.
\end{abstract}

Key words: eutrophic lake, trophic status index, recreation, tourism

\section{Introduction}

The Great Masurian Lakeland is one of the most valuable aquatic ecosystems in the world. It covers an area of approximately $1730 \mathrm{~km}^{2}$, stretching between the Mrągowo Lakeland in the west, the Ełk Lakeland in the east, the Wegorapa Land in the north, and the Masurian Plain in the south. The Great Masurian Lakeland comprises Poland's largest complex of lakes connected by canals, with a total area of $302 \mathrm{~km}^{2}$ (Kondracki 2002). The inter-connected water bodies are divided into three basic lake systems: the northern basin drained by the River Węgorapa occupying an area of $615.167 \mathrm{~km}^{2}$ and a lake cover percentage of $17 \%$, an endorheic central basin with an area of $592.624 \mathrm{~km}^{2}$ and lake cover percentage of $8 \%$, including Lake Mikołajskie, and the largest, southern basin occupying an area of 1961.163 $\mathrm{km}^{2}$ (lake cover percentage just over $8 \%$ ) drained by the River Pisa (Bajkiewicz-Grabowska 2008). The Great Masurian Lakeland contains large and medium lakes (size over $50 \mathrm{ha}$ ), endorheic ones or fluvial-lacustrine systems connecting with other water bodies (e.g. the system of the River Jorka). For landscape and biodiver- sity protection, and biodiversity, small lakes (less than $50 \mathrm{ha}$ ), midfield and midforest ponds, wetlands and peatlands are important. All these elements perform natural, landscape and social functions.

The Great Masurian Lakes are the most popular and most beautiful navigable route in north-eastern Poland. This is an area of unique natural beauty, which is not only rich in historical monuments but also provides opportunities for practising all kinds of water tourism (Jastrzębiec and Kuczkowski 2009). The high appeal of this area attracts one million domestic and foreign tourists, e.g. from Germany, France, Russia.

In the centre of the endorheic middle basin lies the town of Mikołajki, said to be the summer and sailing capital of Mazury. The lake's waterfront is dotted with marinas, taverns and holiday homes. In the high season there are some annual events, such as sailing or shanty contests. Lakes and lake enviorns are attractive for the public and play an important role in recreation and relaxation (Hall and Härkonen 2006; Krukowska and Krukowski 2013). Tourism is associated with intensive use of lakes, for example sailing, power boating, 
water and sunbathingas well as angling (Jastrzębiec and Kuczkowski 2009). Direct and/or indirect use of lakes often has several negative effects which can lead to their degradation. The abuse of lakes and their catchment basins causes changes in the physico-chemical and biological properties of water, which significantly decrease water quality.

The aim of the study was to determine the trophic status of Lake Mikołajskie, which is a hub for tourists sailing or riding motorboats on the Great Masurian Lakes route.

\section{Study area and methods}

Lake Mikołajskie (Fig. 1) is located in the municipality of Mikołajki, in the Mrągowo District (latitude $53^{\circ} 78.2^{\prime} \mathrm{N}$, longitude $21^{\circ} 59.5^{\prime} \mathrm{E}$, elevation $116.1 \mathrm{~m}$ a.s.l). The lake lies midway in a chain of gutter lakes between the towns of Ryn and Ruciane-Nida. Lake Mikołajskie connects with Lake Tałty in the north and lakes Bełdany and Śniardwy in the south (WIOŚ 2014).

The lake has a surface area of 497.9 ha and a maximum depth of $25.9 \mathrm{~m}$. Its basin is elongated along the NW-SE axis. Its maximum length is $5750 \mathrm{~m}$, and maximum width is $1600 \mathrm{~m}$. The shoreline is moderately diversified, as evidenced by the shoreline development index (1.9). Detailed morphometric data are shown in Table 1 (Dunalska 2010).

The total catchment of Lake Mikołajskie covers an area of $1808.7 \mathrm{~km}^{2}$ and its direct catchment an area of $2.3 \mathrm{~km}^{2}$. Much of this area is covered by forests (43.2\%), with smaller percentages of wasteland and developed land (Table 2). The lake is intensively used for

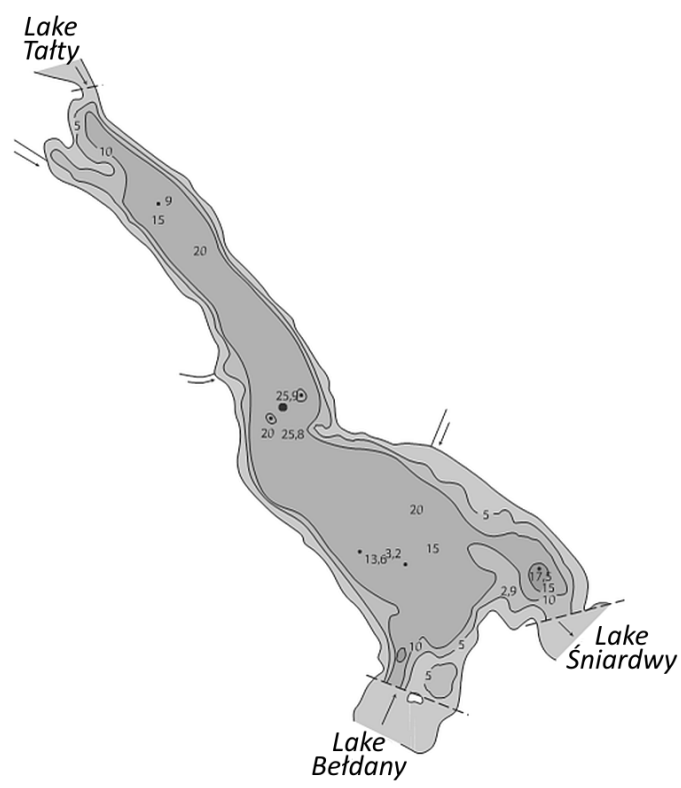

Fig. 1. Bathymetric map of Lake Mikołajskie (according to WIOŚ)
Table 1. Morphometric characteristics of Lake Mikołajskie (according to IRŚ in Olsztyn)

\begin{tabular}{lc}
\hline \multicolumn{1}{c}{ Parameter } & Value \\
\hline Surface rea [ha] & 497.9 \\
\hline Maximum depth [m] & 25.9 \\
\hline Average depth $(\mathrm{m})$ & 11.2 \\
\hline Relative depth & 0.0116 \\
\hline Depth index & 0.43 \\
\hline Volume [dam ${ }^{3}$ ] & 55739.7 \\
\hline Maximum length [m] & 5750 \\
\hline Maximum width [m] & 1600 \\
\hline Elongation [d.u.] & 3.5 \\
\hline Average width [m] & 865 \\
\hline Length of coastline [m] & 15100 \\
\hline Shoreline development [d.u.] & 1.9
\end{tabular}

recreation because of the popular watercourse leading from Mikołajki to Ruciane-Nida and to Lake Śniardwy. The north-eastern part of the lake's shoreline is occupied by buildings which house hotels, resorts, taverns, a port and marinas with water equipment rentals. To the west, the lake is surrounded the Pisz Forest, where there are campsites. The southern and central part of Lake Mikołajskie stretch into the Masurian Landscape Park.

The annual monitoring carried out by the Voivodeship Inspectorate for Environmental Protection (WIOS) revealed that treated wastewater was discharged to Lake Mikołajskie from the holiday resort "Leśna Polana" and from the Hydrobiological Station in Mikolajki. Until 1997 the lake had been receiving untreated wastewater from two small sewage treatments and raw wastewater from many town buildings. In 1997, an automatic-biological sewage treatment plant with a chemical system for removal of phosphorus was built. Now, treated wastewater flows into the southern part of Lake Tałty, and then to Lake Mikołajskie and further to Lake Śniardwy (Dunalska 2010). Despite the expansion and modernization of wastewater management installations, occasional failures of sewage treatment and uncontrolled wastewater discharge can pose a particularly dangerous threat to the purity of Lake Mikołajskie. In addition, approx. $2.5 \mathrm{~km}$ northwest of the lake there is a municipal waste landfill. Another threat to water quality could be posed by the petrol station opened (in

Table 2. Land use in the direct catchment of Lake Mikołajskie (according to WIOŚ)

\begin{tabular}{lrc}
\hline \multirow{2}{*}{ Form of land use } & \multicolumn{2}{c}{ Area (ha) } \\
\cline { 2 - 3 } & {$[\mathrm{ha}]$} & {$[\%]$} \\
\hline Forest & 100.5 & 43.2 \\
\hline Agricultural land & 12.1 & 5.2 \\
\hline Wasteland & 62.3 & 26.8 \\
\hline Built-up areas & 57.7 & 24.8 \\
\hline Total & 232.6 & 100.0 \\
\hline
\end{tabular}


Table 3. Evaluation of susceptibility to degradation of Lake Mikołajskie (according to data WIOŚ)

\begin{tabular}{|c|c|c|c|}
\hline Parameter & Value & Category & Score \\
\hline Maximum depth $[\mathrm{m}]$ & 11.2 & 1 & 1 \\
\hline Volume to shoreline length ratio [ $\mathrm{dam}^{3} \mathrm{~m}^{-1}$ ] & 3.82 & II & 2 \\
\hline Water stratification [\%] & 17.0 & III & 3 \\
\hline Active bottom area to epilimnion volume ratio $\left[\mathrm{m}^{2} \mathrm{~m}^{-3}\right]$ & 0.05 & 1 & 1 \\
\hline Schindler's ratio $\left[\mathrm{m}^{2} \mathrm{~m}^{-3}\right]$ & 32.5 & III & 3 \\
\hline Flushing rate [\%] & 270 & III & 3 \\
\hline \multirow[t]{4}{*}{ Land use in the direct catchment [\%] } & $\begin{array}{c}43.2 \text { - forest } \\
24.8 \text { - built-up areas }\end{array}$ & II & 2 \\
\hline & & Total & 15 \\
\hline & & Average & 2.14 \\
\hline & & Category & II \\
\hline
\end{tabular}

2003) at the sailing port, which supplies fuel to watercrafts (WIOS 2005). However, the main threat to water quality of Lake Mikołajskie is the intense tourist traffic which introduces a large pollutant load in the holiday season.

Lake Mikołajskie belongs to lakes with an average susceptibility to degradation (Table 3 ). The most unfavourable features for lake condition are: per cent of water stratification, the Schindler coefficient (the ratio of the catchment area to lake volume) and the annual water replacement. While the most favourable features are the average depth and the ratio of the active bottom surface to epilimnion volume (Dunalska 2010).

Lake Mikołajskie is one of 22 benchmark lakes included in the diagnostics monitoring network in Poland. It represents a stratified lake classified as a heavily modified water body. Water analyses are carried out by the Voivodeship Inspectorate for Environmental Protection (WIOŚ) in Olsztyn, 6-8 times in the vegetation season each year. The monitoring makes it possible to track the changes in water quality that occur both naturally and under human impact.

The results of selected physicochemical and biological parameters of water quality measured in the years 2013 and 2014 by WIOŚ (2014) were analysed in this study. Afterwards, Carlson's trophic state indices were calculated according to the following simplified equations (Carlson 1977):

$$
\begin{gathered}
T S I(T P)=14.42 \ln (T P)+4.15 \\
T S I(C h l)=9.81 \ln (C h l)+30.6 \\
T S I(S D)=60-14.41 \ln (S D)
\end{gathered}
$$

where: TSI $(T P), T S I(C h l)$ and TSI(SD) are Carlson Trophic State Indices, respectively, for total phosphorus (TP), chlorophyll-a (Chl), and Secchi disc transparency (SD) and is a natural logarithm. TP and chlorophyll- $a$ are in micrograms per litre, and transparency in metres.

\section{Results}

The water temperature in Lake Mikołajskie changed in the analysed season (May-September) depending on the ambient temperature changes. From May, the water temperature gradually increased, peaked in August, and then decreased (Fig. 2). In summer 2013 , it ranged from 10.8 to $22.0^{\circ} \mathrm{C}$, whereas in the next year it varied from 15.3 to $21.1^{\circ} \mathrm{C}$. The $\mathrm{pH}$ of water was comparable in the analysed period, between $8.2-$ 8.5 (Fig. 2). In 2013 electrolytic conductivity changed from 251 to $292 \mu \mathrm{S} \mathrm{cm}-1$. In the following year, it was relatively lower: $230-277 \mu \mathrm{S} \mathrm{cm}-1$. In both years, the
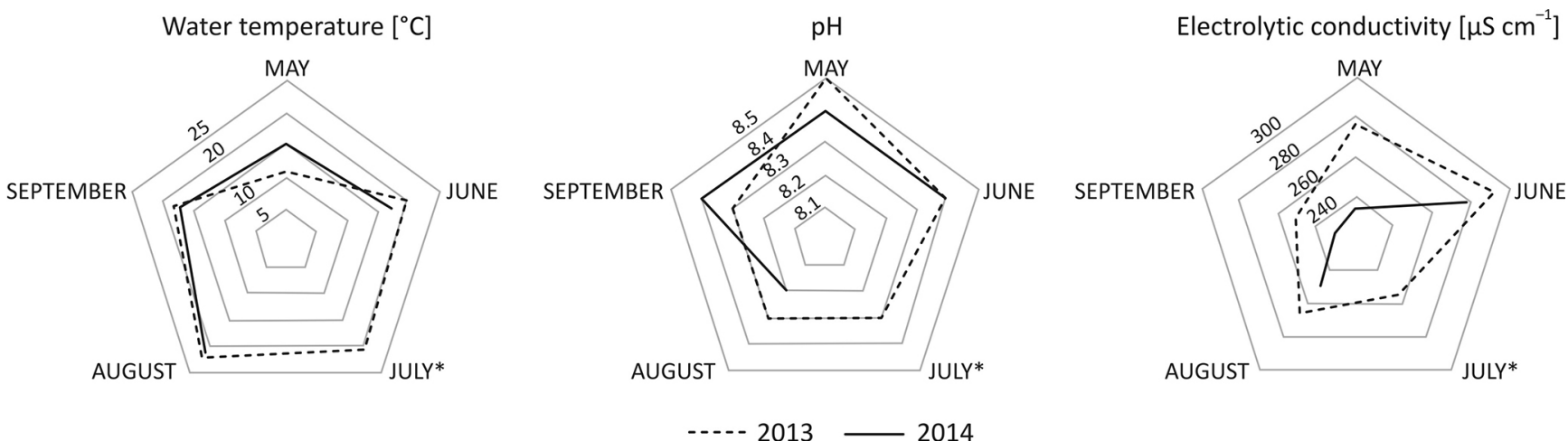

2014

Fig. 2. Physical properties of waters of Lake Mikołajskie in the summer season 2013-2014 ( ${ }^{\star}$ no data July 2014) 

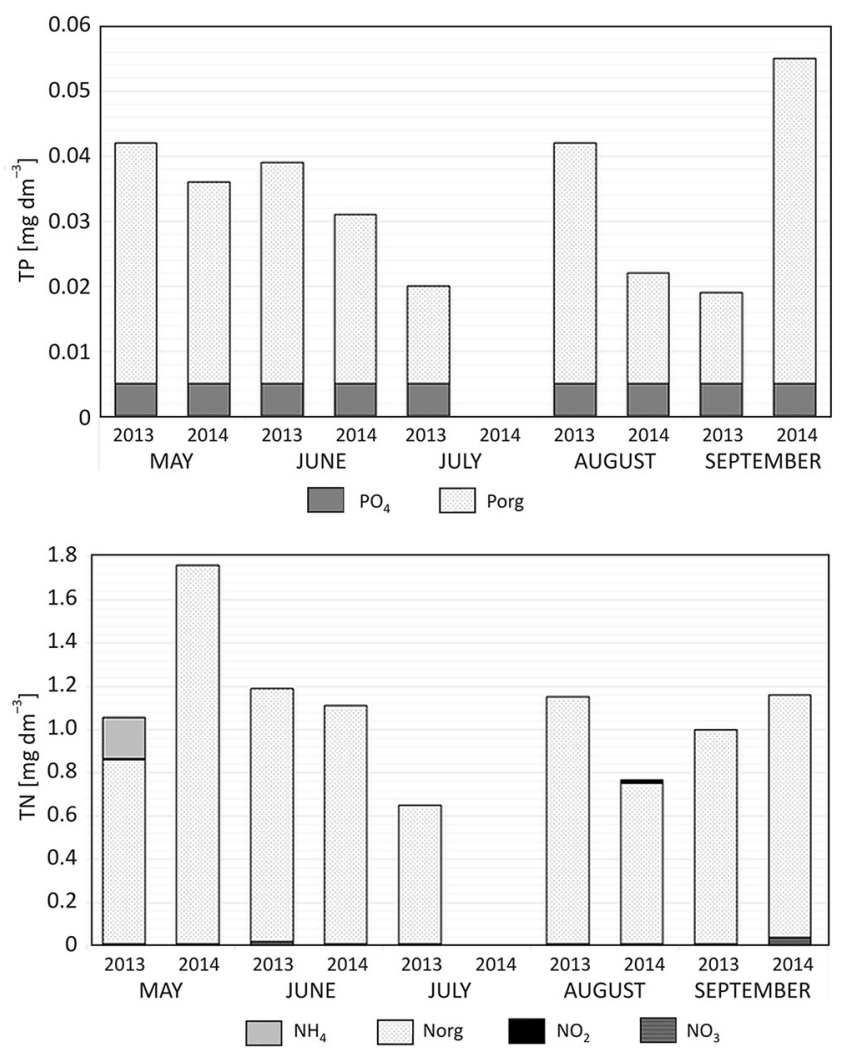

Fig. 3. Concentrations of total phosphorus and total nitrogen in Lake Mikołajskie in the summer season 2013-2014

highest value was recorded in June and the lowest occurred in September (Fig. 2).

In the summer season the concentration of total phosphorus was $0.019-0.042 \mathrm{mg} \mathrm{dm}^{-3}$ in 2013 and $0.022-0.055 \mathrm{mg} \mathrm{dm}^{-3}$ in 2014 (Fig. 3). Maximum values were recorded in August and September. The dominant form of phosphorus was the organic fraction, which accounted for an average of $83 \%$ of total phosphorus. The content of mineral phosphorus remained the same and equalled $0.05 \mathrm{mg} \mathrm{dm}^{-3}$ throughout the study period.

The concentration of total nitrogen ranged within $0.650-1.190 \mathrm{mg} \mathrm{dm}^{-3}$ in 2013 and $0.770-1.760 \mathrm{mg}$ $\mathrm{dm}^{-3}$ in 2014 (Fig. 3). The highest concentrations were recorded in May and June. The dominant form of nitrogen was the organic fraction, which accounted for an average of $96 \%$ of total nitrogen. The content of ammonium nitrogen in the analysed period was $0.01 \mathrm{mg}$ $\mathrm{dm}^{-3}$. Higher values were recorded in June 2013 and September 2014 (respectively 2- and 4-fold higher). Nitrate nitrogen III and V were observed only in May $2013\left(0.05 \mathrm{mg} \mathrm{NO}_{2} \mathrm{mg} \mathrm{dm}^{-3} ; 0.19 \mathrm{mg} \mathrm{NO}_{3} \mathrm{dm}^{-3}\right)$ and in August $2014\left(0.08 \mathrm{mg} \mathrm{NO}_{2} \mathrm{dm}^{-3}\right)$.

In the analysed period, the $\mathrm{TN}$ to $\mathrm{TP}$ ratio ranged from 21 to 53 (Fig. 4). In the summer season 2013, the stoichiometric ratio of the nutrients gradually increased from May to July, after which it declined in

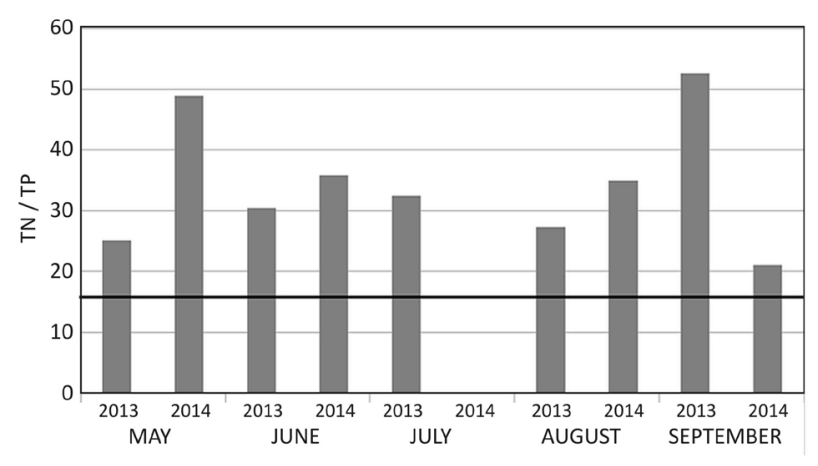

Fig. 4. The stoichiometric ratio for primary production occurring in Lake Mikołajskie (dark line - optimum weight ratio)

August and reached its maximum value in September. The following year, the highest ratio of TN/TP was observed in May, while it was lower in June-August and the lowest in September. Despite the fluctuations between months and years, the TN/TP ratio was higher than an optimum weight ratio by Redfield (16). This indicates that Lake Mikołajskie was significantly rich in nitrogen compounds, while phosphorus had a limiting role in the development of primary production.

The intensity of primary production is also indicated by the transparency of water and content of chlorophyll- $a$. The maximum Secchi disc visibility was $2 \mathrm{~m}$ (May 2013) and $1.8 \mathrm{~m}$ (May, June 2014) (Fig. 5). In the plant growing season of both years water transparency
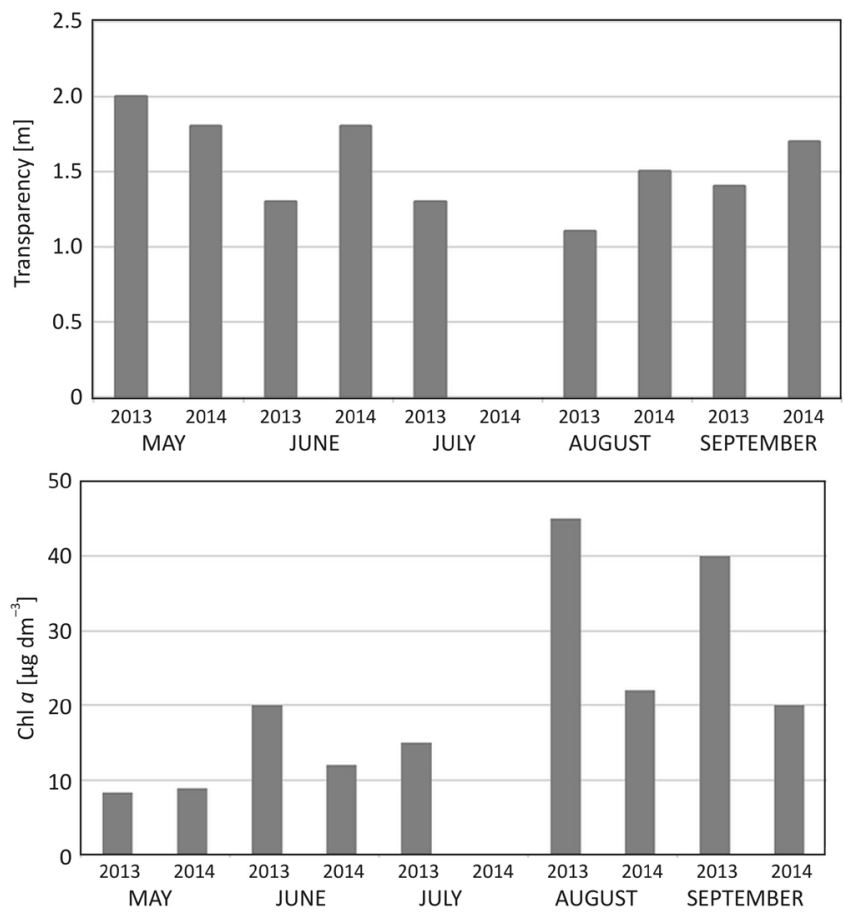

Fig. 5. Water transparency and chlorophyll- $a$ concentrations in Lake Mikołajskie in the summer season 2013-2014 


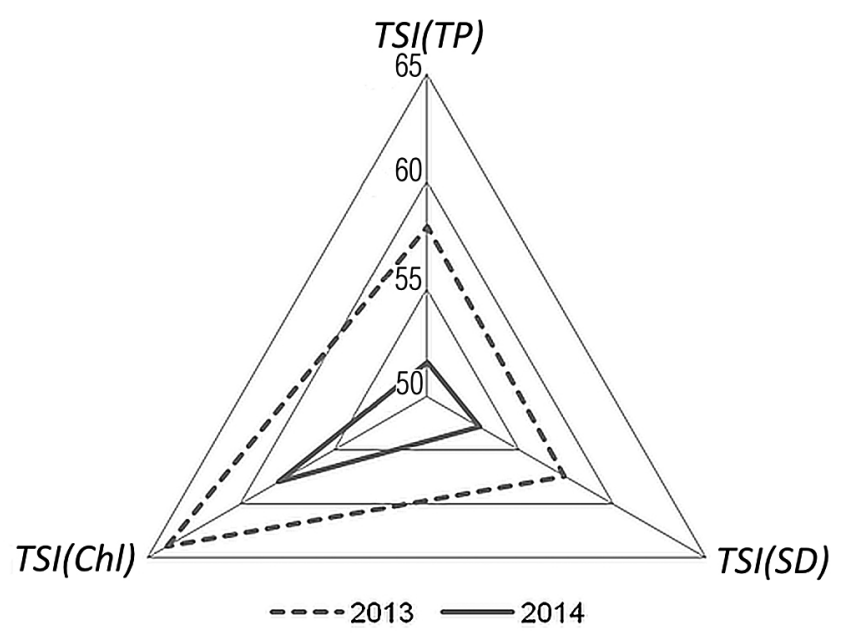

Fig. 6. Diagram of trophic state indices for Lake Mikołajskie in 2013 and 2014

decreased until July/August $(1.3 / 1.1 \mathrm{~m})$, after which it slightly increased and stood at $1.5-1.7 \mathrm{~m}$. The concentration of chlorophyll $a$ was in the range of 8.3-45.0 $\mu \mathrm{g}$ $\mathrm{dm}^{-3}$ in 2013, and 8.9-22.0 $\mu \mathrm{g} \mathrm{dm}^{-3}$ in 2014 (Fig. 5). The highest concentrations were recorded in August in both years.

Based on the concentrations of total phosphorus, transparency and chlorophyll- $a$, the value of the trophic status index by Carlson was calculated s. Mean values for Lake Mikołajskie in 2013 and 2014 were respectively: TSI(TP) 58 and 51, TSI(SD) 57 and 53, TSI(Chl) 64 and 58. In both years, TSI $(C h l)$ dominated. In 2013, $T S I(T P)$ and $T S I(S D)$ were at a comparable level, while in the following year TSI $(S D)$ was slightly higher than TSI (TP) (Fig. 6).

\section{Discussion}

Eutrophication occurs when large amounts of nitrogen and phosphorus from allo- and autochthonous sources are supplied to a lake. The highest amount of these elements reaches water bodies via inflows from drainage basins, surface flow and precipitation. Illegal sewage inflows may be an additional source. Nutrients are also released from bottom sediments in a lake (Hanson et al. 2008; Kajak 2001). The main source of nutrients in Lake Mikołajskie is wastewater discharged into the lake. The refurbished municipal sewage treatment plant discharged approx. $800 \mathrm{~m}^{3} \mathrm{~d}^{-1}$ of wastewater to Lake Tałty in 2013. The inlet of wastewater is only $1 \mathrm{~km}$ from the lake. According to calculations, Lake Mikołajskie could be receiving a load of pollutants consisting of approx. 4.0 tonnes of nitrogen and 0.1 ton of phosphorus per year. Furthermore, the lake was directly supplied withapprox. $10 \mathrm{~m}^{3} \mathrm{~d}^{-1}$ of wastewater from the "Leśna Polana" holiday centre and from the Hydrobiological Station in Mikołajki (WIOŚ 2014).

Both residents and tourists are responsible for the production of these amounts of wastewater. Most of the pollution is transported into sewers and then subjected to mechanical-biological sewage treatment with the chemical removal of phosphorus. However, a large part of the municipality is not connected to the sewage system and household wastewater is collected in septic tanks. If there is a leak in a septic tank, untreated wastewater can permeate into soil and surface waters. Furthermore, the largest source of pollution in the lake is considered to be sailing boats which directly introduce wastewater into Lake Mikołajskie. Although ecomarinas are equipped with modern infrastructure for wastewater collection from watercraft, they are not used very frequently. An additional source of nutrients delivered to Lake Mikołajskie can also be in the form of fish bait. Its intensive use by anglers supplies the lake with large amounts of nutrients and minerals.

The predominance of organic forms of nutrients and the depletion of mineral phosphorus and ammonium ions in the surface layers indicate intensive primary production occurring in the lake. The optimal stoichiometric ratio of $\mathrm{N}$ to $\mathrm{P}$ is $16: 1$. In the considered time this ratio was higher, which suggests that phosphorus was a nutrient that limited primary production in Lake Mikołajskie. Then, the abundance of water in nitrogen compounds primarily affects the growth and dominance of blue-green algae in the lake (Vrede et al. 2002). Both the increase in $\mathrm{pH}$ and water temperature may intensify cyanobacterial blooms. Excessive growth of cyanobacteria can lead to extinction of fish and displacement of indigenous species (plants and animals) by invasive species (Vrede et al. 2002). In the Great Masurian Lakes, and specifically in Lake Mikołajskie and Lake Kuc, the presence of invasive alien species namely Elodea nuttaleni and Elodea canadensis was detected. Nitrogen compounds in water are conducive to the growth of these species (Woźniak-Wilk et al. 2012).

Higher concentrations of organic nitrogen observed in the summer months indicate the enrichment of water in this form of nitrogen. It mainly had an autochthonous character, resulting from the intensively growing phytoplankton in the lake. The content of chlorophyll- $a$ in phytoplankton, amount of organic and mineral suspended matter and colour all affect Secchi depth. In 2013 the process of primary production was higher than in the following year. In the summer (June-September) the concentration of chlorophyll$a$ in the water was almost twice as high, while water transparency was lower than $0.5 \mathrm{~m}$. The calculated from the content of total phosphorus, chlorophyll- $a$ and transparency classifies the water in Lake Mikołajskie 
as eutrophic. Further interpretation of the provides information about the functioning of the ecosystem and factors limiting primary production. was higher than, which may indicate the dominance of cyanobacteria in phytoplankton (Carlson 1977; Szymański et al. 2014). Intensification of this phenomenon would be very disadvantageous because cyanobacteria can produce toxic compounds.

Furthermore, the eutrophication of Lake Mikołajskie has been increased by natural environmental factors, including climate change. The increased frequency and intensity of natural disturbances recorded in recent years may cause the mixing of the entire volume of water. This is associated with huge amounts of nutrients from the bottom sediments being introduced to all trophic layers. Global warming increases water temperature, which can stimulate the growth of bluegreen algae. A rapid response to changes is characteristic of blue-green algae, which are adaptable to habitats and able to compete effectively and dominate under unstable environmental conditions. Changes in the structure of phytocoenoses (increase in the proportion of invasive thermophilic and highly toxic blue-green algae) can lead to the exclusion of a lake from recreational use (Dunalska 2010).

An overall assessment of the water status in accordance with the guidelines contained in the Regulation of the Minister of Environment of 15 November 2011 indicates the poor state of Lake Mikołajskie (GIOS 2014). Based on the monitoring studies of WIOS in 2013-2014, the ecological potential changed from low to moderate, and the chemical status remained good (WIOŚ 2014). Physicochemical elements, such as electrolytic conductivity, concentration of total phosphorus and total nitrogen in the analysed summer seasons did not exceed threshold values for the good status of water $\left(600 \mu \mathrm{S} \mathrm{cm}^{-1} ; 0.075 \mathrm{mg} \mathrm{TP} \mathrm{dm} \mathrm{dm}^{-3} ; 2.0 \mathrm{mg} \mathrm{TN}\right.$ $\mathrm{dm}^{-3}$ ). The main adverse impact on the condition of water in Lake Mikołajskie was produced by biological elements, which resulted in the ecological potential of the lake being less than good. In the analysed period, Phytoplankton Metric for Polish Lakes decreased from 3.45 to 2.92, changing the status of water to moderate. In addition, the third class of water purity is indicated by other parameters, i.e. Ecological State Macrophyte Index $(\mathrm{ESMI}=0.34)$, Multimetric Diatom Index for Lakes $(\mathrm{IOJ}=0.77)$ and Lake Fish Index $(\mathrm{LFI}=0.44)$ (WIOŚ 2014). Among the water quality parameters analysed in Lake Mikołajskie in 2010-2013, the lowest variability (13-23\%) was determined for the physicochemical parameters. The highest variation was detected for biological parameters (23-25\%), while cyanobacteria biomass varied within the range of $65 \%$ (GIOŚ 2014). This proves the ongoing intensive primary production and hence progressing eutrophication.

Both the natural processes occurring in lake and the increased input of pollutants in summer months affect the water quality in Lake Mikołajskie. The increasing eutrophication of the lake is a consequence of its attractiveness. Every year, the summer capital of Masuria attracts more and more tourists, which tempts local residents to derive material benefits from tourism. More and more land around the lake is developed for holiday resorts. The land development, especially in the surroundings of Lake Mikołajskie, has destroyed its buffer zone. This has limited the natural protection of the lake against the inflow of nutrients.

\section{Conclusion}

The water quality of Lake Mikołajskie depends primarily on the manner and intensity of the recreational use of the lake and its catchment. For recreational functions lakes should contain clean and clear water. In turn, lake surroundings should create opportunities for both land and water tourism. The attractiveness of Lake Mikołajskie and its surroundings has long been stimulating tourism, which has affected the trophic state of waters. The pollution produced by land tourists is directed to the sewage system, but in water tourism sanitary tanks are often emptied directly into the lake instead of using the facilities at ecomarinas. Not only the massive influx of tourists, but also activity of the residents dictated by economic reasons contribute to pollution of lake. The current state of water quality has been significantly influenced by the an uncontrolled discharge of untreated sewage and sporadic failures of municipal sewage treatment.

In order to protect the lake from degradation, tourists should be informed about the rational use of surface waters and the surrounding catchment. Recreational activity should be more carefully monitored by administrative authorities, one particularly important aspect being to ensure that sanitation tanks are emptied in ecomarinas. The development of tourism and economy of this region should be harmonious and balanced, so that the natural resources will be able to serve us and future generations for as long as possible. .

\section{References}

Bajkiewicz-Grabowska E., 2008, Obieg wody w systemie Wielkich Jezior Mazurskich (The water circuit in the Great Masurian Lakes system), [in:] Jasser I., Robak S., Zdanowski B. (eds), Ochrona i rekultywacja Wielkich Jezior Mazurskich narzędziem rozwoju naukowego, gospodarczego, społecznego i kulturowego regionu (Pro- 
tection and restoration of the Great Masurian Lakes as a tool for scientific, economic, social and cultural development of the region), Wyd. IRŚ, Olsztyn: 19-31.

Carlson R.E, 1977, A trophic state index for lakes, Limnol. Oceanogr. 22(2): 361-369.

Dunalska J., 2010, Morfometria i zlewnia jezior Kuc, Majcz Wielki i Mikołajskiego (Morphometry and catchment of lakes Kuc, Majcz Wielki and Mikołajskie) [in:] Dunalska J. (ed.), Warunki środowiskowe i stan troficzny jezior Kuc, Majcz Wielki i Mikołajskiego (Environmental conditions and trophic status of lakes Kuc, Majcz Great and Mikołajskie), Wydaw. UWM, Olsztyn: 9-19 (in Polish).

[GIOŚ] Główny Inspektorat Ochrony Środowiska (Chief Inspectorate of Environmental Protection), 2014, Analiza zmian stanu jednolitych części wód powierzchniowych jeziornych reperowych w latach 2010-2013 (Analysis of changes in the status of benchmark lake waterbodies in 2010-2013) [Typescript], GIOŚ, Warszawa, $92 \mathrm{pp}$. (in Polish). Retrieved from: http://www.gios.gov.pl/images/dokumenty/pms/monitoring_wod/JezioraReperowe2010_2013.pdf.

Hall C.M., Härkonen T., 2006, Lake tourism: an introduction to lacustrine tourism systems, [in:] Hall C.M., Härkonen T. (eds), Lake tourism. An integrated approach to lacustrine tourism systems, Aspect of tourism, Channel View Publications, Clevedon: 3-26.

Hanson P.C., Carpenter S.R., Kimura N., Wu C., Cornelius S.P., Kratz T.K., 2008, Evaluation of metabolism models for free-water dissolved oxygen methods in lakes, Limnol. Oceanogr. Methods 6: 454-465.

Jastrzębiec Kuczkowski W., 2009, Szlak Wielkich Jezior Mazurskich. Przewodnik dla turystów wodnych (Route of the Great Masurian Lakes. Guide for water tourists), Ofic. Wydaw. „Alma-Press”, Warszawa, 349 pp. (in Polish).

Kajak Z., 2001, Hydrobiologia - limnologia. Ekosystemy wód śródlądowych (Hydrobiology - limnolog. Inland water ecosystems), Wydaw. Nauk. PWN, Warszawa, 360 pp. (in Polish).

Kondracki J., 2002, Geografia regionalna Polski (Regional geography of Poland), Wydaw. Nauk. PWN Warszawa, 441 pp. (in Polish).
Krukowska R., Krukowski M., 2013, Spatial differentiation of tourist infrastructure in the riparian zone of the Białe Lake (Middle-East Poland), Pol. J. Nat. Sci.28(1):89-97.

[WIOŚ] Wojewódzki Inspektorat Ochrony Środowiska (Voivodship Inspectorate of Environmental Protection), 2005, Raport o stanie środowiska województwa warmińsko-mazurskiego w 2004 roku (Report on the state of the environment of the Warmia and Mazury in 2004) IOŚ-WIOŚ, Olsztyn, 109 pp. (in Polish).

[WIOŚ] Wojewódzki Inspektorat Ochrony Środowiska (Voivodship Inspectorate of Environmental Protection), 2014, Raport o stanie środowiska województwa warmińsko-mazurskiego w 2013 roku (Report on the state of the environment of the Warmia and Mazury in 2013), IOŚ-WIOŚ, Olsztyn, 121 pp. (in Polish).

Szymański D., Dunalska J., Brzozowska R, Sieńska J., Zieliński R., 2014, Ocena stanu troficznego jezior miejskich Olsztyna na podstawie indeksu Carlsona (Assessment of the trophic status of urban lakes located in Olsztyn on the basis the Carlson's index), [in:] Traczewska T.M., Kaźmierczak B. (eds), Interdyscyplinarne zagadnienia w inżynierii i ochronie środowiska. T. 4. (Interdisciplinary issues in engineering and environmental protection. Vol. 4), Ofic. Wydaw. PWr., Wrocław: 872-880 (in Polish, English summary).

Vrede K., Heldal M., Norland S., Bratbak G., 2002, Elemental composition ( $, \mathrm{N}, \mathrm{P})$ and cell volume of exponentially growing and nutrient-limited bacterioplankton, Appl. Environ. Microbiol. 68(6): 2965-2971.

Woźniak-Wilk E., Gąbka M., Grabowska M., Karpowicz M., Kokocioski M., Kołodziejczyk A., Kuczyoska-Kippen N., Messyasz B., Nagengast B., Ozimek T., Paczuska B., Pełechaty M., Pęczuła W., Pietryka M., Pociecha A., Pukacz A., Richter D., Walusiak E., Żbikowski J, 2012, 3150 Starorzecza i naturalne eutroficzne zbiorniki wodne ze zbiorowiskami Nympheion, Potamion (3150 Oxbows and natural eutrophic water bodies with communities of Nympheion, Potamion), [in:] Mróz W. (ed.), Monitoring siedlisk przyrodniczych, Przewodnik metodyczny (Monitoring of natural habitats. Methodical guidebook), IOŚ, Warszawa: 14-29 (in Polish). 
